\title{
Revisiting the limnology of Lake Río Cuarto, Costa Rica, thirty-five years later
}

\author{
Gerardo Umaña-Villalobos ${ }^{1,2} \&$ Aldo Farah-Pérez ${ }^{1,2}$ \\ 1. Escuela de Biología, Universidad de Costa Rica, San Pedro, San José 2060, Costa Rica; gerardo.umana@ucr.ac.cr; \\ farahaldo@gmail.com \\ 2. Centro de Investigación en Ciencias del Mar y Limnología (CIMAR), Ciudad de la Investigación, Universidad de \\ Costa Rica, San Pedro, San José 2060, Costa Rica
}

Received 16-I-2017. Corrected 07-VI-2017. Accepted 03-I-2018.

\begin{abstract}
Lake Río Cuarto is a meromictic lake at low elevation in the North of Costa Rica. It offers an opportunity to compare its present state with the condition it had when first studied in the late 1970's and occasional samplings since then. This comparison expects to identify changes that could be attributed to incipient effects of global climate change. We studied the limnology and conditions of its drainage area for three years (2013-2016) to compare with previous data. Vertical profiles of temperature, dissolved oxygen, conductivity, $\mathrm{pH}$, chlorophyll a, dissolved $\mathrm{H}_{2} \mathrm{~S}$ were performed several times per year, for a total of 22 samplings. Aerial photographs taken since 1950 were analyzed to describe land use changes. The lake had a shallow Secchi depth $(<5 \mathrm{~m})$ at all times. It was stratified on all occasions, with a thermocline that fluctuated between 10 and $20 \mathrm{~m}$. It has a monimolimnion, with a chemocline at 14 to $22 \mathrm{~m}$. Below the chemocline it was always anoxic, and during annual partial mixing events in the mixolimnion, oxygen levels decreased compared to stratified periods. There was a continuous presence of $\mathrm{H}_{2} \mathrm{~S}$ from $20 \mathrm{~m}$ downwards, with annual fluctuations, being lower during partial mixing events. A peak in chlorophyll was detected on all occasions just below the thermocline. Land use around the lake hasn't changed much since 1952, when only a rim of tree cover was left around the steep margins of the lake. The lake has maintained its limnological characteristics, with the only exception that it didn't cooled down to historical levels. This limited response could be the result of the high relative depth and steep margins of the lake, which prevent the downward distribution of heat and keeps the lake in a meromictic state, preventing its mixing for long periods of time. Rev. Biol. Trop. 66(Suppl. 1): S42-S52. Epub 2018 April 01.
\end{abstract}

Key words: Tropical limnology, climate change, land use, Lake Río Cuarto.

In spite of being an outstanding feature of any landscape, which led Forbes (1887 cited in Kalff, 2002) to consider them as a microcosm, lakes are open systems subject to the influences of external factors such as the weather, geological and landscape conditions. As such, they show temporal variations some of which can be considered cyclic in a more or less seasonal pattern, but others show more unidirectional or long-term changes. This is true for lakes all over the Globe. There is a general paucity of long term studies of tropical ecosystems, but in particular a lack of data for lakes. It is important to include lakes and how they respond in the general knowledge that is being documented about the effects of climate change in the tropics (Alfaro \& Amador, 1996; Gómez \& Fernández, 1996; Alvarado, Contreras, Alfaro, \& Jiménez, 2012). One such opportunity has been offered by some large lakes in Africa where studies were performed in the 1950's and 1960's and later compared with recent data such as Lake Tanganyika (Plisnier, 2000; O'Reilly, Alin, Plisnier, Cohen, \& McKnee, 2003; Verburg, Hecky, \& Kling, 2003). Few studies in Neotropical lakes have addressed the impact of climate change because long term data are lacking. In addition, recent land 
use changes may confound the effects of global environmental change in these developing nations. Lately an opportunity to monitor a lake in Costa Rica for ten years gave some hints of the impact of climate change in recent times (Umaña, 2014). Yet the time frame was short to draw a definitive conclusion. Lake Río Cuarto, in the low hills of the northern plains of Costa Rica, offers such an opportunity since it was first studied in 1954 (Kohkemper, 1954) and has received further attention since (Gocke, Bussing, \& Cortés, 1987, 1990; Charpentier et al., 1988; Horn \& Habeyan, 1993; Haberyan, Horn, \& Umaña, 2003).

Since the first studies in Lake Río Cuarto, the greenhouse effect on global climate has intensified. Its consequences for lakes varies with their geographic location. An increase in productivity has been reported in temperate regions, attributed to an increase in the metabolic rate of phytoplankton with temperature as well as an increase in the decomposition rates of organic matter which enhances nutrient availability (DeStasio, Hill, Kleinhans, Nibbelink, \& Magnuson, 1996; Porter, Saunders, Haberyan, \& Macubbin, 1996; Jeppesen et al., 2011). Another effect has been an intensification of the stratification and a reduction of the thermocline depth (Winder \& Hunter, 2008), which caused changes in phytoplankton composition in Lake Tahoe. In tropical regions, warming also produces a stronger stratification. As a result, nutrient supply in the euphotic zone is reduced which leads to dwindling phytoplankton productivity and an increase in water transparency in deep lakes such as lakes Tanganyika and Kivu (Plisnier, 2000; O'Reilly et al., 2003; Verburg et al., 2003; Lorke, Tietze, Halbwachs, \& Wüest, 2004) whereas in the shallow Lake Victoria, an increase in productivity has been observed since the lake does not stratify (Hecky et al., 1994). Studies on recent trends in Costa Rica have shown an increase in temperature anomalies which are consistent with global trends (Alfaro \& Amador, 1996; Gómez \& Fernández, 1996). Nevertheless, there are local variations as a consequence of the topographic heterogeneity of the country.
More recent studies by the National Meteorological Institute-IMN have developed the most probable forecast for the country (Comité Regional de Recursos Hidráulicos, 2008; Consultoría Ecológica y Técnica de Costa Rica (ECOTEC), 2009; Alvarado et al., 2012). Their results forecast an expected warming for the region where Lake Río Cuarto is located. In the present study, the basic limnology of Lake Río Cuarto is revisited and compared with previous studies in order to observe if its main characteristics have changed, and whether those changes are in accordance with the expected influence of climate change or if other factors could be also at play.

\section{MATERIALS AND METHODS}

The lake Río Cuarto is a maar lake located within a crater (Alvarado, Soto, Salani, Ruiz, \& de Mendoza, 2011) on the hills in the Sarapiquí low plains, north of Costa Rica $\left(10.3572^{\circ} \mathrm{N}\right.$ $84.2189^{\circ} \mathrm{W}$ ), at 380 masl. It has an almost circular outline with a surface area of 31.52 ha and a maximum depth of $66 \mathrm{~m}$ (Gocke et al., 1987). It has a high relative depth of $10.4 \%$, which is among the highest of world lakes (Kalff, 2002). It was visited in several occasions between January 2013 and April 2016 for a total of 22 sampling visits. The lake was sampled between 11:00 and 12:00 each time. On every occasion, the Secchi depth was recorded along with depth profiles of temperature, $\mathrm{pH}$, dissolved oxygen, specific conductivity, turbidity in Nephelometric turbidity units and chlorophyll by means of a fluorometer, all mounted on a multiparameter probe (Model YSI 6600 V2). Water samples were taken every ten meters and the concentration of $\mathrm{H}_{2} \mathrm{~S}$ was measured with a $\mathrm{Hach}{ }^{\circledR}$ HS-WR test kit, immediately upon withdrawal of the sampling Alpha bottle. Nutrient levels (ammonim, nitrite, nitrate and phosphate) were measured on filtered water samples at the same depths. Samples were kept in a cooler for transport to the Marine Chemistry Laboratory at CIMAR, where all nutrients were determined with an autoanalizer (Model Labchat 8500) based on Parsons, Maita, \& Lalli (1984). 
Simple linear models were performed in order to test for tendencies of change in time of $\mathrm{pH}$, conductivity and sulfide concentrations at fixed depths. Comparison of nutrient levels at different depths was made with an ANOVA test with repeated measurements. These tests were carried out using R statistical software.

In order to examine the potential effect of land use changes on the lake, aerial photographs were obtained in a digital format at the National Geographic Institute of Costa Rica for the years 1952, 1960, 1971, 1984, 1992, and 2005. Drainage area was first outlined in a topographic map of the area (Figure S1), scale 1:50000, and later modelled from the digital elevation model of the "Atlas Digital de Costa Rica” (Soto-Mayor \& Ortiz-Malavasi, 2008) using ESRI ArcGis 10.1. Land uses were classified into the following categories: roads, tree cover, pasture and agricultural land, buildings and lake area.

\section{RESULTS}

Secchi disk readings varied between 1.8 and $4.9 \mathrm{~m}$, with a fluctuation pattern that repeated every two years within the period of study, increasing from January to November (Fig. 1). Temperature at the surface fluctuated between 27 and $30{ }^{\circ} \mathrm{C}$ and remained at 24.2 ${ }^{\circ} \mathrm{C}$ at $45 \mathrm{~m}$ of depth which was the deepest point reached with the sensor cable. A wellrecognized thermocline was located between
6 and $16 \mathrm{~m}$. Its depth increased from January to November each year (Fig. 2). However, during the study period there were occasions of partial mixing in the epilimnion, especially in January and February, but also in July and August, when the surface waters cooled down by $1{ }^{\circ} \mathrm{C}$ to $1.5^{\circ} \mathrm{C}$. There was also a tendency of the thermocline to establish at a greater depth from 2013 to 2016, although it was not significant $\left(\mathrm{F}_{1,21}=3.95 ; \mathrm{p}=0.059\right)$. Mixing was not complete at any time during the observation period, and the hypolimnion persisted below 20 $\mathrm{m}$ depth. Oxygen levels reached $8.7 \mathrm{mg} / \mathrm{L}$ at the surface but decreased sharply between 7 and 16 $\mathrm{m}$. Oxygen levels in the hypolimnion remained almost anoxic on all visits. In the epilimnion there were episodes of low oxygen concentration during the times of partial mixing (Fig. 2), especially at the beginning of 2016 .

Values of $\mathrm{pH}$ were high at the surface, between 8.2 and 8.8. A gradient was observed also between 7 and $16 \mathrm{~m}$ of depth, with values around 6.8 below the $16 \mathrm{~m}$ on all visits (Fig. 3). However, a decreasing trend can be observed in the hypolimnion from 2013 to 2016, which became more acidic towards the end of the observation period $\left(\mathrm{F}_{1,17}=29.28 ; \mathrm{p}=0.00005\right)$. During mixing events in 2015 and 2016, there was a decrease in $\mathrm{pH}$ in the epilimnion. Specific conductivity fluctuated between 116 and $190 \mu \mathrm{Si} / \mathrm{cm}$, with lower values in the epilimnion, and a clear chemocline at $20 \mathrm{~m}$ depth, which however became deeper with time $\left(\mathrm{F}_{1,21}\right.$ $=30.8 ; \mathrm{p}=0.00002)$. Conductivity increased in

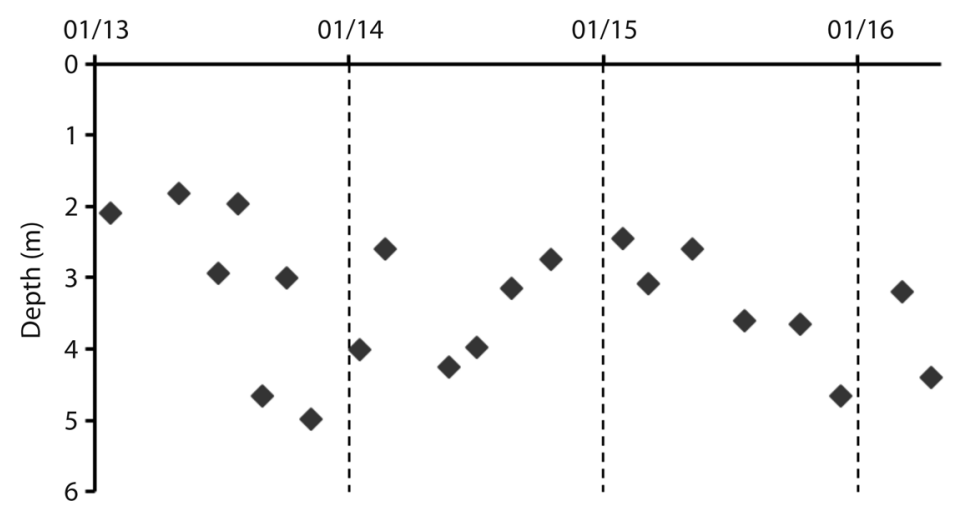

Fig. 1. Secchi disk visibility along the study period (2013-2016). 

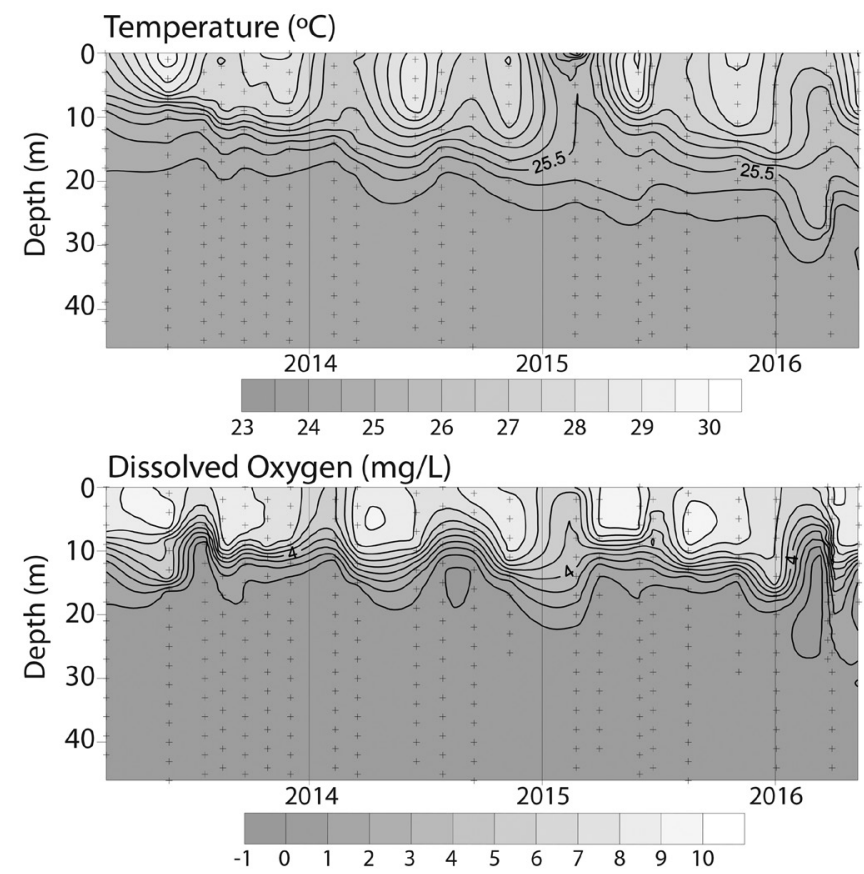

Fig. 2. Depth time isolepths of Temperature and dissolved oxygen in Lake Río Cuarto along the study period.
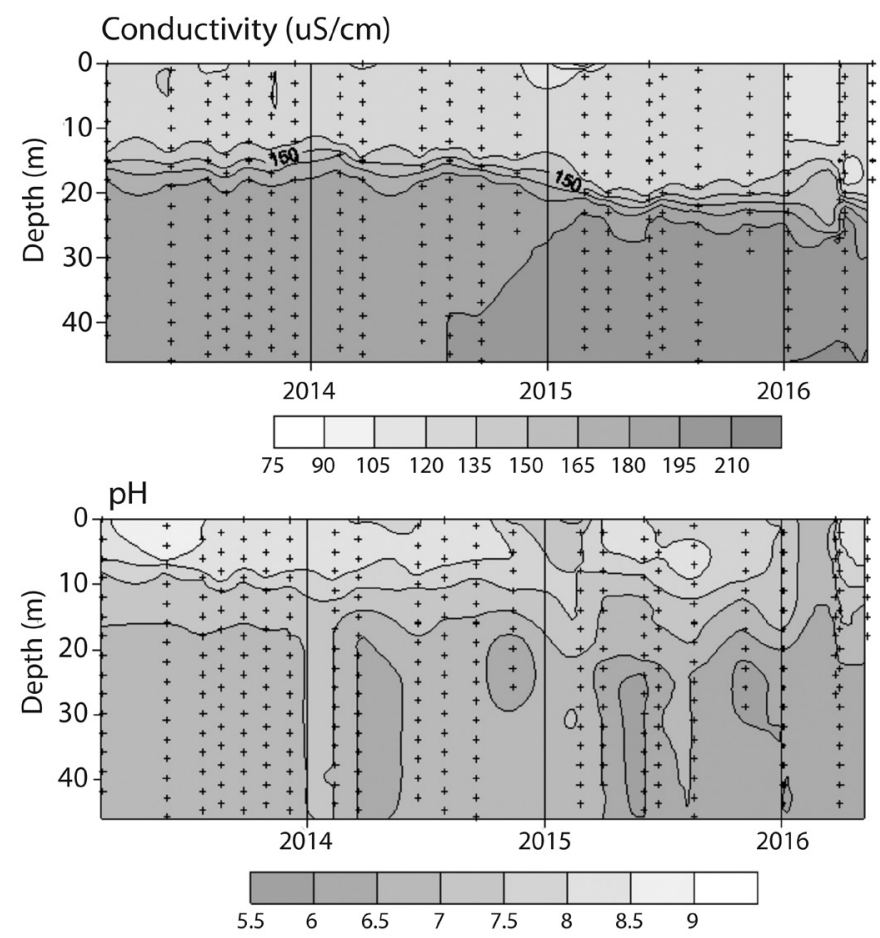

Fig. 3. Depth time isolepths of specific conductivity and pH in Lake Río Cuarto, during the study period. 
the hypolimnion over the course of this study, especially at the deepest part of the lake (Fig. 3) $\left(\mathrm{F}_{1,17}=586.8 ; \mathrm{p}<0.0001\right)$.

The concentration of $\mathrm{H}_{2} \mathrm{~S}$ was below the detection level $(<0.6 \mu \mathrm{mol} / \mathrm{L})$ at the surface and $10 \mathrm{~m}$ depth and increased at $20 \mathrm{~m}$ depth. Samples taken at $15 \mathrm{~m}$ did not have the smell of the gas. Levels of this gas, which reached up to $10.0 \mu \mathrm{mol} / \mathrm{L}$, fluctuated with time, with a maximum that occurred during the last half of each year, and a decrease just at the end of the mixing period (Fig. 4). A peak of chlorophyl was detected just below the thermocline (Fig. 4). Chlorophyll, as measured with a fluorometer, always showed a peak at mid depth, between 14 and 20 to $24 \mathrm{~m}$ of depth, but actual depth varied with date (Fig 4), with a tendency to increase with time $\left(\mathrm{F}_{1,15}=7.795 ; \mathrm{p}=0.0137\right)$. Maximum values at the peak varied between 10 and $64 \mu \mathrm{g} / \mathrm{L}$.

Nutrient levels in the lake varied little with time, but some showed vertical stratification
(MANOVA Wilks $=0.38 ; \mathrm{p}=0.000^{* * *}$ ) (Fig. 5). Phosphate varied from levels below the detection limit of the method $\left(4 \mu \mathrm{g} \mathrm{P}_{-} \mathrm{PO}_{4} / \mathrm{L}\right)$, and up to $16 \mu \mathrm{g} \mathrm{P}-\mathrm{PO}_{4} / \mathrm{L}$, with no distinct vertical distribution $\left(\mathrm{F}_{5,90}=1.138 ; \mathrm{p}=0.23 \mathrm{NS}\right)$. Nitrate also was undetectable on some dates and attained the highest concentration of 18 $\mu \mathrm{g} \mathrm{N}-\mathrm{NO}_{3} / \mathrm{L}$ on January 2015 with a tendency to be higher in the epiliminion $\left(\mathrm{F}_{5,90}=2.83 ; \mathrm{p}\right.$ $=0.02 *$ ). Ammonium varied widely between 0.2 and $967.4 \mu \mathrm{g} \mathrm{N}-\mathrm{NH}_{4} / \mathrm{L}$, with a big increase below $20 \mathrm{~m}$, just below the thermocline $\left(\mathrm{F}_{5,90}\right.$ $\left.=18.52 ; \mathrm{p}=0.000^{* * *}\right)$. Nitrite was uniformly distributed in the water column $\left(\mathrm{F}_{5,90}=1.54 ; \mathrm{p}\right.$ $=0.18 \mathrm{NS}$ ).

The analysis of aerial photographs and satellite images since the 1950's until 2000, of the area that drains directly into the lake reveals that most of the area was deforested by the 1950's (Fig. 6), with minor increments afterwards. The main activity around the lake has been cattle ranching at low density, with
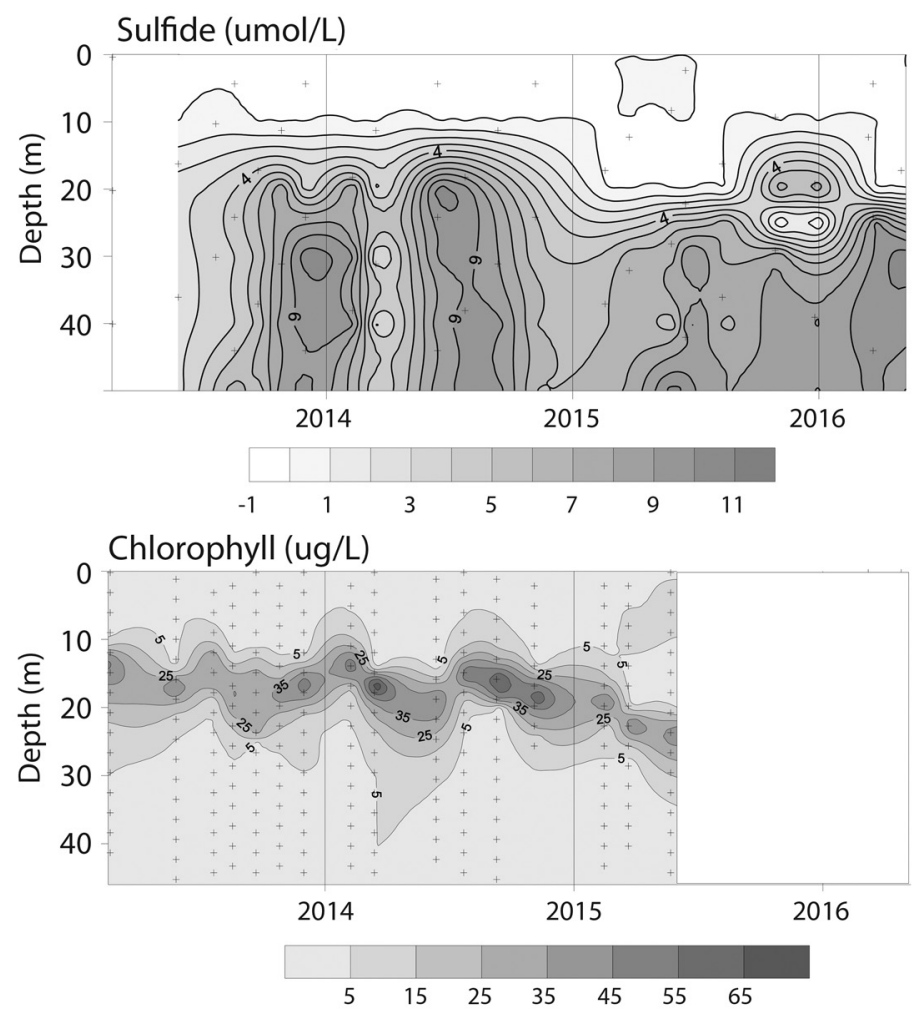

Fig. 4. Depth time isolepths of sulfhydric acid $\left(\mathrm{H}_{2} \mathrm{~S}\right)$ and chlorophyll in Lake Río Cuarto, during the study period. 

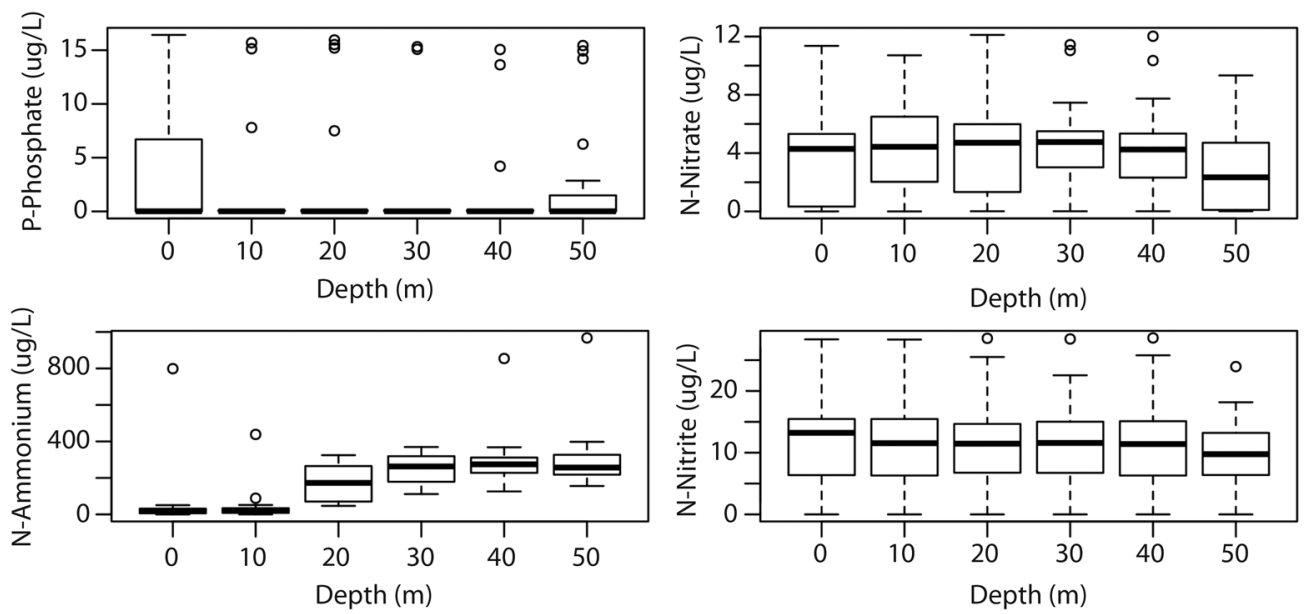

Fig. 5. Boxplot of the variation of phosphate-P, nitrate-N, ammonium-N and nitrite-N at fixed depths in Lake Río Cuarto.

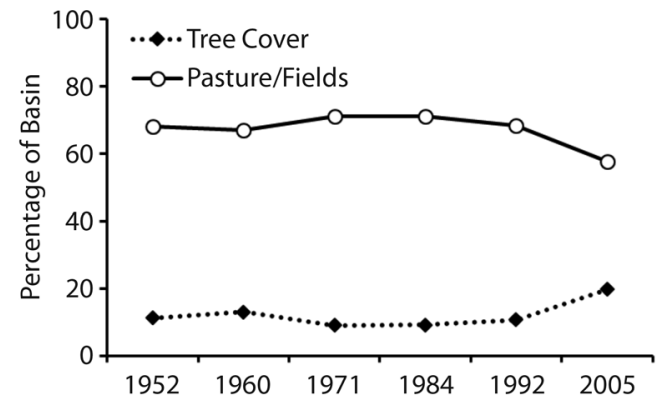

Fig. 6. Change of percentage cover of tree cover and pasture / agriculture in the drainage basin of Lake Río Cuarto at different times since 1952. Values were calculated based on aerial photographs and Remote Sensor Images available at the National Geographic Institute of Costa Rica. Total area $=152 \mathrm{Ha}$. Lake area $=30 \mathrm{Ha}$.

periods where the land was used for other uses, such a pineapple plantations. At the moment, it is again used for cattle grazing. Most of the left forest cover is located in the steep rim immediately around the lake and to the southeast of it since the earliest aerial photograph analyzed.

\section{DISCUSSION}

The first studies on the lake date back to 1954 by Kohkemper. Later the lake was studied again by Gocke and coworkers who sampled the lake between 1978 and 1979 studying its basic limnology, morphometry and primary productivity (Gocke et al., 1987; 1990). In the decade of 1980's Charpentier et al. (1988) also performed a study between 1984 and 1985 . Horn \& Haberyan (1993) also studied the lake in 1992 and again in 1997 (Haberyan et al., 2003). All these studies were made with a different objective in mind but nevertheless they all recorded some basic limnological data about the lake. Surface temperatures have been recorded to vary between 24.6 and $30{ }^{\circ} \mathrm{C}$. In the present study, the values fluctuated between 27 and $30{ }^{\circ} \mathrm{C}$ and never cooled down to the historical minimum registered in earlier studies. Bottom temperatures however have remained consistently just above $24{ }^{\circ} \mathrm{C}$, which coincides well with the expected temperature of $23.0{ }^{\circ} \mathrm{C}$ according to altitude and latitude of the lake following Lewis (1987) empirical criterion.

The lake was clearly stratified as a result of the vertical change in temperature, together with the increment in conductivity with depth. Although the increase in water density is rather small, with a maximum difference across the water column that varied between 0.85 and 1.77 $\mathrm{Kg} / \mathrm{m}^{3}$ during this study, the high relative depth and sheltered location within the crater rim prevent frequent mixing in this tropical lake. In Gocke's study the thermocline was located between 20 and $25 \mathrm{~m}$ of depth. Charpentier 
et al. (1988) found that the thermocline was between 12 and $25 \mathrm{~m}$, and the more recent study of Horn \& Haberyan (1993) reported a thermocline between 11 and $13 \mathrm{~m}$ and later they reported a value of $8 \mathrm{~m}$ in 1997 (Haberyan et al., 2003). In the present study, the thermocline was located between 6 and $16 \mathrm{~m}$ in 2013, however, from 2013 until 2016 a clear deepening of the thermocline occurred, down to a similar depth as that observed in those earlier studies. There were two partial mixing events per year, one during the hemispherical winter (January to February, and occasionally early March), which was expected, since it is the time of stronger Easterly winds in the region. And a second partial mixing event, albeit milder, was observed in the middle of the year, between July and August or September. This second mixing was unexpected, and occurs during the rainy season, may be as a result of large precipitation events during that time. The intensity and exact timing of each mixing event varies among years.

In accordance with the thermal structure of the water column, oxygen concentration and conductivity also showed a steep gradient. In the present study, the oxycline was located between 8 and $15 \mathrm{~m}$ of depth, with some variation with time. In 1978-1979 the oxycline was located at 20-25 m of depth (Gocke et al., 1987 ) with a variation between January with $6.5 \mathrm{mg} / \mathrm{L}$ at the surface and higher values in May $(>10 \mathrm{mg} / \mathrm{L})$ and September $(\sim 9 \mathrm{mg} / \mathrm{L})$. In this case there was an unexpected result. During the partial mixing events oxygen levels in the epilimnion declined instead of increasing and resulted in a more uniform distribution of oxygen through the mixed column. A similar situation was observed at Lake Bonilla, Costa Rica (Umaña, 2016). In both lakes there is an accumulation of sulfhydric acid in the hypolimnion. Mixing causes the upwelling of the sulfide laden waters, and as a result oxygen is exhausted by the oxidation of sulfide. This situation is a clear distinction to what has been mentioned as the normal situation in temperate lakes, where mixing brings a deep oxygenation of the lake (Kalff, 2002; Wetzel,
2001). Reports from other meromictic lakes with sulfide laden monimolimnia like Lake Shira, Russia (Rogozir, Genova, Gulati, \& Degermendzhy, 2010), Mono Lake (Melack \& Jellison, 1998) and Big Soda Lake (Cloern, Cole, \& Oremland, 1983) show that mixolimnia do not become oxygen deprived during mixing periods as occurred in Lake Río Cuarto. One possible reason for this is that in tropical lakes temperatures are high even during deep mixing events, higher than $20^{\circ} \mathrm{C}$ in most cases, and particularly in Lake Río Cuarto which is located at low elevation. This high temperature affects oxygen solubility and also favors high reaction rates, which may facilitate the oxidation of sulfur and other compounds, exhausting the dissolved oxygen in a short time.

The chemocline in this study spanned from 10 to $20 \mathrm{~m}$ in all sampled dates. This gradient in conductivity was also reported by previous studies at different depths. Gocke et al. (1987) reported it to be below $25 \mathrm{~m}$ of depth. Charpentier et al. (1988) mentioned a chemocline at $12 \mathrm{~m}$ of depth, with higher values in May and October in comparison to January and February. Haberyan et al. (2003) found the chemocline at $8 \mathrm{~m}$ of depth. In the current study, conductivity showed less temporal variation in respect to the position of the chemocline, although a small increase in the hypolimnion and a decline in the epilimnion was observed during the study period. The observed decrease in $\mathrm{pH}$ with depth was also reported in previous studies in the lake. However, surface values were higher than 8 in the present study, a unit higher than those reported by Gocke et al. (1987) but lower than the the $\mathrm{pH}$ reported in 1997 by Haberyan et al. (2003). In the present study $\mathrm{pH}$ showed a sharp gradient between 5 and $10 \mathrm{~m}$ and a more gradual decrease down to $20 \mathrm{~m}$ of depth.

Another factor that may contribute to the stratified condition of the lake is the input of groundwater loaded with dissolved substances of volcanic origin. Although it has not been determined, this deep input is assumed to be important since the only source of surface input for the lake comes from a small inlet 
at the south, and given that the lake has nevertheless a permanent outlet, there must be a groundwater input. The presence of a relatively high concentration of $\mathrm{H}_{2} \mathrm{~S}$ in the lower part of the lake is another reason to think that the lake receives most of its water from the aquifer, which is affected by the volcanic activity in the region (Alvarado et al., 2011). This gas sometimes reaches values higher than the 6 $\mu \mathrm{mol} / \mathrm{L}$ reported by Gocke et al. (1987). These higher concentrations occur as shallow as 20 $\mathrm{m}$ of depth, in contrast to the $25 \mathrm{~m}$ reported by Gocke and coworkers. Sulfide concentrations were within the observed range in other meromictic lakes in the World, but far from the highest reported values. For example, in Paul Lake (Michigan, $13 \mathrm{~m}$ deep and 1 ha surface area, $\mathrm{Zr}=11.52), \mathrm{H}_{2} \mathrm{~S}$ values can reach 20 $\mu \mathrm{mol} / \mathrm{L}$ (Taillefert, Lienemann, Gaillard, \& Perret, 2000). In Lake Cadagno $\left(0.26 \mathrm{~km}^{2}\right.$ and $20 \mathrm{~m}$ deep, $\mathrm{Zr}=3.47)$ in southern Swiss Alps $\mathrm{H}_{2} \mathrm{~S}$ can reach up to $1000 \mu \mathrm{mol} / \mathrm{L}$ (Bosshard, Santini, Grüter, Sttetler, \& Bachofen, 2000). The sulfide source in this case is the dolomite rocks in its drainage basin (Tonolla, Peduzzi, Demarta, Peduzzi, \& Hahn, 2004). These latter authors report a $\mathrm{H}_{2} \mathrm{~S}$ value of $70 \mu \mathrm{mol} / \mathrm{L}$ and the monimolimnion extends from $13 \mathrm{~m}$ down.

This situation led Gocke et al. (1987) to classify the lake as meromictic, although in a second paper they changed its classification to oligomictic (Gocke et al., 1990). It is not yet clear whether deep mixing, which can produce high mortalities of fish in the lake, are really holomictic events or rather partial mixing events or atelomixis as defined by Lewis (1973). The fish kills come about due to the toxicity of the $\mathrm{H}_{2} \mathrm{~S}$ brought up by the turbulence, and its oxidation to sulfate which exhausts dissolved oxygen (Infante, Infante, Marquéz, Lewis, \& Weibezahn, 1979; Effler et al., 2004), and in this lake, it is also a result of the relatively large volume of water that is anoxic and loaded with the toxic gas. An increasing trend with time in the concentration of this gas also indicates that not all deep mixing events, if frequent enough may produce the fish kills since the buildup of lethal levels of the gas may take time to accumulate. According to Kalff (2002) meromixis, requires two conditions: first, a low vulnerability to wind mixing either due to sheltering from the surroundings or to morphometry (a high $\mathrm{Zr}$ ), and second, some source of salinity or accretion of dissolved substances in the deeper layers of the lake. It might also be the result of an event that loads the lake with fresher water on top, which raises its level to the point the whole lake mixing becomes more difficult, as happened in Mono Lake (Melack \& Jellison, 1998). This last case also agree with the opinion that meromixis does not mean forever, but rather several years of no whole lake overturn (Boehrer \& Schultze, 2010), a fact that was also stressed by Lewis (1983) who concluded that a lake can be meromictic in some years and holomictic in others. According to these definitions, one can consider Lake Río Cuarto as meromictic. This shows that it is important to perform long term studies of many more tropical lakes, since one year of data may not reveal a lake's whole behavior.

Finally, the general physical limnology of Lake Río Cuarto does not show much change since the first studies in the lake in 1978-1979, that could be attributed to climate change. It is still a meromictic lake, with high $\mathrm{H}_{2} \mathrm{~S}$ concentration in the monimolimnion. The lake is not much warmer than previous reports, although surface temperatures were always higher than reported historical minimum. Deep waters had the same temperature perhaps because it is deep enough to prevent heating in the monimolimnion. In a recent review of twenty years of data of 17 Danish lakes, Özkan et al. (2016) also found that many lakes showed no trends in water column stability with time, so, it seems that not all lakes respond in a similar manner to climate change, as is the case in Río Cuarto. Mixing patterns revealed in this study demonstrate that the lake is more dynamic than previously thought. Although the thermocline at the beginning of this study was shallower, it was similar to situations found in the 1990's by former studies such as reported by Haberyan \& Horn (1999), and by the end of the study it 
reached similar depths as reported by Gocke et al. (1987) in 1978-1979. Water transparency, although in some occasions was smaller than values observed in 1982 (Umaña, 1985) and 1991 (Horn \& Haberyan, 1993), the whole range is similar to historical values. Historical trophic state of the lake can be assessed from these Secchi readings, since previous studies in the lake didn't include chlorophyll or phosphorus determinations. According to this information, the lake has remained between a mesotrophic to eutrophic state during the past 30 years. Land use around the lake hasn't change much either and could not be taken as responsible to the mild changes observed in the lake in the recent decades, since the region was deforested already by 1952 .

\section{RESUMEN}

Revisitando la limnología del lago Río Cuarto, Costa Rica, treinta y cinco años después. El Lago de Río Cuarto es un lago meromíctico de baja altitud en el norte de Costa Rica, y ofrece la oportunidad de comparar su estado actual con las condiciones que tenía cuando fue estudiado con detalle al final de los 1970's y muestreos ocasionales realizados desde entonces. Esta comparación permitiría observar si ha habido cambios que se puedan atribuir al cambio climático global. Nosotros estudiamos la limnología y las condiciones de su área de drenaje, por tres años (2013-2016) con el fin de comparar con los datos anteriores. Se realizaron perfiles verticales de temperatura, oxígeno disuelto, conductividad, $\mathrm{pH}$, clorofilas y $\mathrm{H}_{2} \mathrm{~S}$ disuelto, varias veces por año para un total de 22 visitas. Se analizaron también fotografías aéreas tomadas desde 1952 para detectar cambios en el uso del suelo. El lago presentó una profundidad de Secchi baja $(<5 \mathrm{~m})$ en todo momento. Estuvo estratificado en todas las ocasiones, con una termoclina que fluctuó entre los 10 y $20 \mathrm{~m}$. Posee un monimolimnion, con una quimioclina entre los 14 y $22 \mathrm{~m}$. Por debajo de la termoclina siempre estuvo anóxico, y durante eventos de mezcla parcial del mixolimnion, los niveles de oxígeno disminuyeron en comparación a los periodos de estratificación. Hubo una continua presencia de $\mathrm{H}_{2} \mathrm{~S}$ a partir de los $20 \mathrm{~m}$, con fluctuaciones anuales y una disminución en los eventos de mezcla parcial. Se detectó un pico de clorofila en todo momento, justo debajo de la termoclina. El uso de la tierra no ha cambiado mucho pues desde la década de 1950 sólo quedaba cobertura arbórea en la fuerte pendiente alrededor del lago. El lago ha mantenido muchas de sus características limnológicas, solamente se observó que el epilimnion no se llegó a enfriar a los mismos niveles que históricamente. Esta falta de respuesta puede ser debido a la profundidad del lago y sus empinadas orillas, que evitan la distribución del calor.

Palabras clave: Limnología tropical, cambio climático, uso del suelo, Lago Río Cuarto

\section{REFERENCES}

Alfaro, E., \& Amador, J. A. (1996). El Niño-Oscilación del Sur y algunas series de temperatura máxima y brillo solar en Costa Rica. Tópicos Meteorologicos y Oceanograficos, 3, 19-26.

Alvarado, G. E., Soto, G. J., Salani, F. M., Ruiz, P., \& de Mendoza, L. H. (2011). The formation and evolution of Hule and Río Cuarto maars, Costa Rica. Journal of Volcanology and Geothermal Research, 201, 342356. Doi:10/.1016/j.jvolgeores.2010.12.017

Alvarado, L. F., Contreras, W., Alfaro, M., \& Jiménez, E. (2012). Escenarios de cambio climático regionalizados para Costa Rica. San José, Costa Rica: MINAET-IMN-PNUD.

Boehrer, B., \& Schultze, M. (2010). Density stratification and stability. In G. E. Likens (Ed.). Lake ecosystem ecology: a global perspective (pp. 96-106). Amsterdam, Netherlands: Elsevier.

Bosshard, P.P., Santini, Y., Grüter, D., Sttetler, R., \& Bachofen, R. (2000). Bacterial diversity and community composition in the chemocline of the meromictic alpine Lake Cadagno as revealed by $16 \mathrm{~S}$ rDNA analysis. FEMS Microbial Ecology, 3,. 173-182.

Charpentier, C., Tabash, F. A., Fallas, I. A., Zumbado, J. C., Camacho, L., \& Ramírez, E. (1988). Variación estacional en el lago de Río Cuarto, provincia de Alajuela, Costa Rica. I. Limnología físico-química. Uniciencia, 5(1/2), 77-85.

Cloern, J. E., Cole, B. E., \& Oremland, R. S. (1983). Seasonal changes in the chemistry and biology of a meromictic lake (Big Soda Lake, Nevada, USA). Hydrobiologia, 105, 195-206.

Comité Regional de Recursos Hidráulicos. (2008). El clima, su variabilidad y cambio climático en Costa Rica. San José, Costa Rica: MINAET-IMN-PNUD-CRRH.

DeStasio, B. T. Jr., Hill, D. K., Kleinhans, J. M., Nibbelink, N. P., \& Magnuson, J. J. (1996). Potential effects of global climate change on small north-temperate lakes: physics, fish and plankton. Limnology and Oceanography, 41, 1136-1149.

Consultoría Ecológica y Técnica de Costa Rica (ECOTEC). (2009). Diagnóstico biofisico para Costa Rica. Informe Final. San José, Costa Rica: IMN-PNUD-MINAE.

Effler, S. W., Wagner, B. A., O’Donnell, S. M., Matthews, D. A., O’Donnell, D. M., Gelda, ... Cowen, E. A. 
(2004). An upwelling event at Onondaga Lake, NY: characterization, impact and recurrence. Hydrobiologia, 511, 185-199.

Gocke, K., Bussing, W., \& Cortés, J. (1987). Morphometric and basic limnological properties of the Laguna de Río Cuarto, Costa Rica. Revista de Biología Tropical, $35(2), 277-285$.

Gocke, K., Bussing, W., \& Cortés, J. (1990). The annual cycle of primary productivity in Laguna de Río Cuarto. Revista de Biología Tropical, 38(2B), 387-394.

Gómez, I. E., \& Fernandez, W. (1996). Variación interanual de la temperatura en Costa Rica. Tópicos Meteorologicos y Oceanograficos, 3, 27-44.

Haberyan, K., \& Horn, S. P. (1999). Chemical and physical characteristics of seven volcanic lakes in Costa Rica. Brenesia, 51, 85-95.

Haberyan, K, Horn, S. P., \& Umaña, G. (2003). Limnology of fifty-one lakes in Costa Rica. Revista de Biología Tropical, 51, 107-122.

Hecky, R. E., Bugenyi, F. W. B., Ochumba, P., Talling, J. F., Mugidae, R., Gophen, M., Kaufman, L. (1994). Deoxygenation of the deep water of Lake Victoria, East Africa. Limnology and Oceanography, 39, $1476-1481$

Horn, S. P., \& Haberyan, K. A. (1993). Physical and chemical properties of Costa Rican lakes. National Geographic Research and Exploration, 9(1), 86-103.

Infante, A. de, Infante, O., Marquéz, M., Lewis, W. M. Jr., \& Weibezahn, F. H. (1979). Conditions leading to mass mortality of fish and zooplankton in Lake Valencia, Venezuela. Acta Científica Venezolana, $30,67-73$.

Jeppesen, E., Kronvang, B., Olesen, J. E., Audet, J., Søndergaard, M., Hoffmann, C. C., ... Özkan, K. (2011). Climate change effects on nitrogen loading from cultivated catchments in Europe: implications for nitrogen retention, ecological estate of lakes and adaptation. Hydrobiologia, 663, 1-21.

Kalff, R. (2002). Limnology, inland water ecoystems. New Jersey, USA: Prentice Hall.

Kohkemper, M. J. (1954). Bosquejo limnológico de la Laguna del Misterio (Licenciatura's thesis). San José, Costa Rica: Universidad de Costa Rica.

Lewis, W. M. Jr. (1973). The thermal regime of Lake Lanao (Phillipines) and its theoretical implications for tropical lakes. Limnology and Oceanography, $18,200-217$.

Lewis, W. M. (1983). A revised classification of lakes based on mixis. Canadian Journal of Fisheries and Aquatic Sciences, 40, 1779-1787.
Lewis, W. M., Jr. (1987). Tropical limnology. Annual Review of Ecology and Systematics, 18, 159-184.

Lorke, A., Tietze, K., Halbwachs, M., \& Wüest, A. (2004). Response of Lake Kivu stratification to lava flow and climate warming. Limnology and Oceanography, 49, 778-783.

Melack, J. M., \& Jellison, R. (1998). Limnological conditions in Mono Lake: contrasting monomixis and meromixis in the 1990's. Hydrobiologia, 384, 21-29.

O'Reilly, C. M., Alin, S. R., Plisnier, P. D., Cohen, A. S., \& McKnee, B. A. (2003). Climate change decreases aquatic ecosystem productivity of Lake Tanganyika, Africa. Nature, 424, 766-768.

Özkan, K., Jeppesen, E., Davidson, T. A., Bjerring, R., Johansson, L. S., Søndergaard, M., ... Svenning, J. C. (2016). Long-term trends and temporal synchrony in plankton richness, diversity and biomass driven by re-oligotrophication and climate across 17 Danish lakes. Water, 8, 427. Doi: 10.3390/w8100427.

Parsons, T. R., Maita, Y., \& Lalli, C. M. (1984). A manual of chemical and biological methods for seawater analysis. Oxford, England: Pergamon Press.

Plisnier, P. D. (2000). Recent climate and limnological changes in lake Tanganika. Verhandlung der Internationalis Vereiningung Limnologie, 27, 1-4.

Porter, K. G., Saunders, P. A., Haberyan, K. A., \& Macubbin, A. E. (1996). Annual cycle of autotrophic and heterotrophic production in a small, monomictic Piedmont lake (Lake Oglethorpe): Analog for the effects of climatic warming on dimictic lakes. Limnology and Oceanography, 41, 1041-1051.

Rogozir, D. Y., Genova, S. N., Gulati, R. D., \& Degermendzhy, A. G. (2010). Some generalizations based on stratification and vertical mixing in meromictic Lake Shira, Russia, in the period 2002-2009. Aquatic Biology, 44, 485-496. DOI: 10.1007/s10452-010-9328-6.

Soto-Mayor, C., \& Ortiz-Malavasi, E. (Eds.). (2008). Atlas digital de Costa Rica. Cartago, Costa Rica: Instituto Tecnológico de Costa Rica.

Taillefert, M., Lienemann, C. P., Gaillard, J. F., \& Perret, D. (2000). Speciation, reactivity, and cycling of $\mathrm{Fe}$ and $\mathrm{Pb}$ in a meromictic lake. Geochimica et Cosmochimica Acta, 64(2), 169-183.

Tonolla, M., Peduzzi, S., Demarta, A., Peduzzi, R., \& Hahn, D. (2004). Phototrophic sulfide and sulfatereducing bacteria in the chemocline of meromictic Lake Cadagno, Switzerland. Journal of Limnology, 63, 161-170.

Umaña, G. (1985). Phytoplankton species diversity of 27 lakes and ponds of Costa Rica (Central America) (Master's thesis). Saint Catherines, Canada: Brock University. 
Umaña, G. (2014). Ten years of limnological monitoring of a modified natural lake in the tropics: Cote Lake, Costa Rica. Revista de Biología Tropical, 62, 567-578.

Umaña, G. (2016). One year weekly dynamics of limnological conditions and phytoplankton in Lake Bonilla, Costa Rica. Revista de Biología Tropical, 64, 1771-1781.
Verburg, P., Hecky, R. E., \& Kling, H. (2003). Ecological consequences of a century of warming in Lake Tanganyika. Science, 301, 505-507.

Wetzel, R. G. (2001). Limnology, lake and river ecosystems. San Diego, CA: Academic Press.

Winder, M., \& Hunter, D. A. (2008). Temporal organization of phytoplankton communities linked to physical forcing. Oecologia, 156, 179-192.

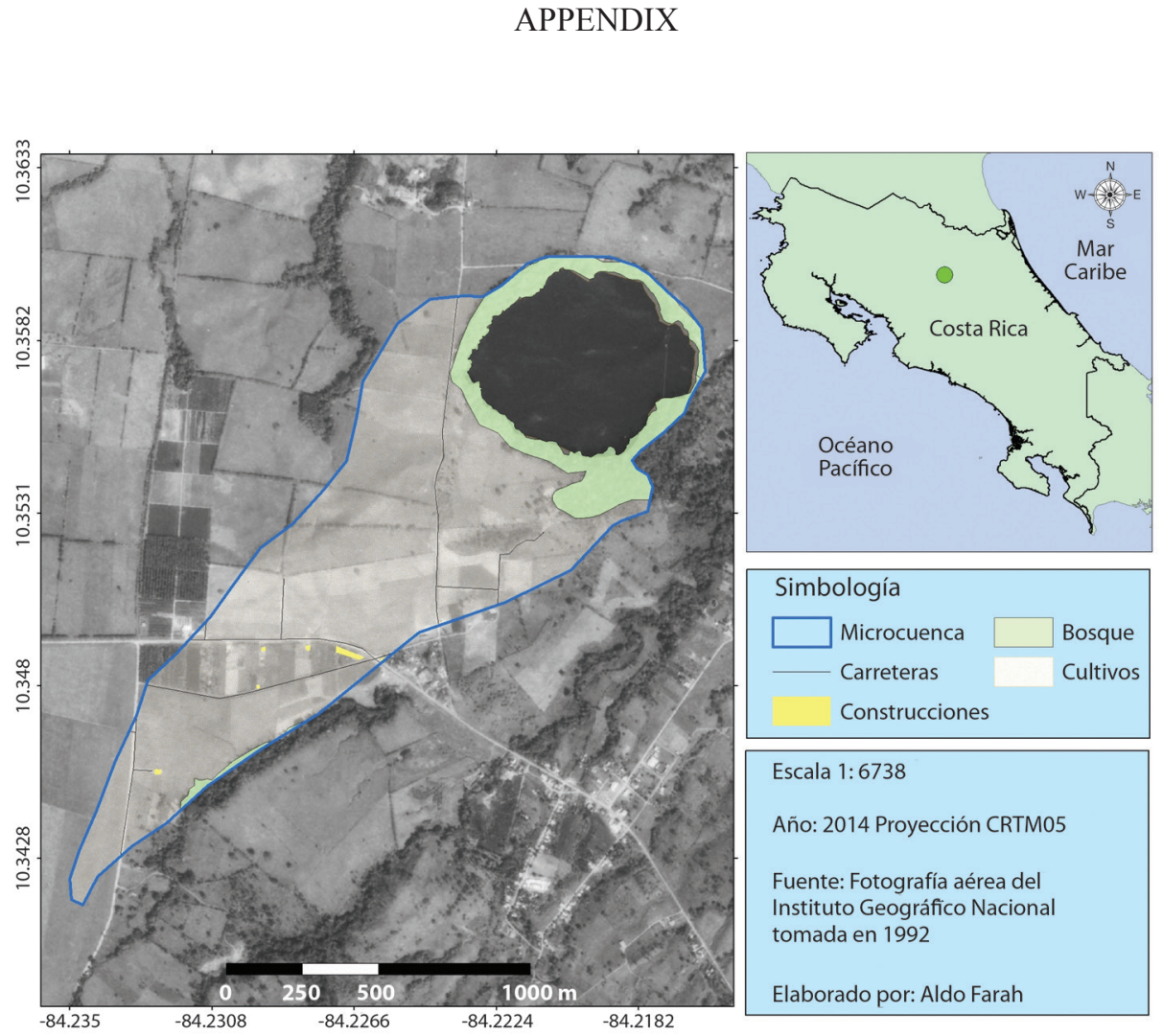

Fig. S1. Outline of the drainage basin of lake Río Cuarto used to calculate land use cover. 